\title{
AN ANALYSIS OF DEATHS IN TULISZKÓW PARISH CAUSED BY A CHOLERA EPIDEMIC IN 1831
}

\author{
ANALIZA ZGONÓW W PARAFII TULISZKÓW SPOWODOWANYCH \\ EPIDEMIĄ CHOLERY W 1831 ROKU
}

\author{
Place of work: Retired \\ Miejsce pracy: Emerytura
}

\begin{abstract}
BACKGROUND. Information is presented about cholera as an infectious disease and an epidemic in Polish lands and in Europe in 1831 based on old and modern sources.

OBJECTIVE. To analyze the difference in the percentages of deaths from cholera depending on age, in the Tuliszków parish during the cholera epidemic in 1831.

MATERIAL AND METHODS. A query was carried out in the archives. Information on deaths between 1829 and 1839 was obtained from the parish registry files. The following factors were taken into account: the cause of death, the age of the deceased and the place of residence. For individual age groups, the numbers of people who died of cholera in 1831 and those who died from other causes in the control year 1835 were compared by the Fisher test. The GBL and PubMed database was searched using the keywords: cholera, cholera epidemic, deaths, Tuliszków, the year 1831, Holy Spirit Hospital, Konin.

RESULTS. An outbreak of cholera in Tuliszków parish in 1831 began around the 8th of August and lasted until about the 10th of October. 81 people died of cholera: 74 people in Tuliszków and 7 people in Sarbicko. The number of deaths in infants and children up to 5 years of age was in fact significantly lower than in other age groups $(\mathrm{p}=0.0052)$. The percentage of deaths from cholera compared to deaths from other causes among infants and children under 5 years of age decreased from $52.46 \%$ to $28.4 \%$. In the age group of 20 to 40 years old it increased from $13.11 \%$ to $23.46 \%$ and in the age group over 55 years from $9.84 \%$ to $19.75 \%$.
\end{abstract}

CONCLUSIONS. In Tuliszków parish in 1831, the number of deaths of infants and children under 5 years of age caused by cholera was indeed significantly lower than in other age groups $(\mathrm{p}=0.0052)$.

Key words: cholera, children, epidemic, infants, Tuliszków

\section{STRESZCZENIE}

WSTĘP. Przedstawiono wiadomości o cholerze jako chorobie zakaźnej i epidemii na ziemiach polskich i w Europie w 1831 roku na podstawie źródeł dawnych i współczesnych.

CEL. .Zbadanie zmiany rozkładu odsetka zgonów zmarłych na cholerę w zależności od wieku w parafii Tuliszków, podczas epidemii cholery w 1831 roku.

MATERIAL I METODY. Wykonano kwerendę w archiwach. Informacje o zgonach w latach od 1829 do 1839 roku uzyskano z akt parafialnych stanu cywilnego. Brano pod uwagę: przyczynę zgonu, wiek zmarłego, miejsce zamieszkania. Dla poszczególnych grup wieku liczby zmarłych na cholerę w roku 1831 i zmarłych z innych przyczyn w roku kontrolnym 1835 porównano testem Fishera. Przeszukano bazę danych GBL i PubMed. stosując hasła: cholera, epidemia cholery, zgony, Tuliszków, rok 1831, szpital św. Ducha, Konin.

WYNIKI. Epidemia cholery w parafii Tuliszków w 1831 roku miała początek około 8 sierpnia i trwała do około 10 października. Na cholerę zmarło 81 osób, w tym w Tuliszkowie (74 osoby) i w Sarbicku (7 osób). Liczba zgonów niemowląt i dzieci do lat 5 była istotnie mniejsza niż w pozostałych grupach wieku $(\mathrm{p}=0.0052)$. Odsetek zgonów spowodowanych cholerą w porównaniu do zgonów z innych przyczyn wśród niemowląt i dzieci do 
lat 5 zmalał z 52,46\% do 28,4\%. W grupie wieku od 20 do 40 lat wzrósł z 13,11\% do 23,46\% a w grupie wieku powyżej 55 roku życia z 9,84\% do $19,75 \%$.

WNIOSKI. W parafii Tuliszków w 1831 roku spowodowana cholerą liczba zgonów niemowląt i dzieci do lat 5 była istotnie mniejsza niż w pozostałych grupach wieku $(\mathrm{p}=0.0052)$.

Słowa kluczowe: cholera, dzieci, epidemia, niemowlęta, Tuliszków.

\section{INTRODUCTION}

The second pandemic of cholera began in 1829 in India, from where it spread to Russia, Polish lands occupied by the invading countries, Germany, Sweden, Austria and England. China and the USA were also impacted (1). The spread of various epidemics was enhanced by mass movements of the population due to the desire to improve living conditions or due to military activities such as mobilization, wars, refugee migration and demobilization. The occurrence of cholera sometimes caused social unrest (2). Although the November Uprising coincided with the cholera epidemic in 1831, it did not result from it.

Due to shortage of hospitals adequate care was not provided. People did not want to entrust the sick to them. However, there were no revolts related to distrust of doctors, which occurred in other European cities $(2,3)$. On July 26, 1831, The Central Committee of Health appointed free practitioners with the task of helping regional physicians in order to treat and assist patients in private homes (4). It was the world's first equivalent of today's family doctor.

The purpose of the uprising was not to change social relations, which was the claim by the Russian side with the purpose to discourage others from helping Poles in any way. Because Poles were fighting for independence, they could not recognize the tsar's proclamation (5). The opinion that the emigration of Polish refugees caused by the uprising resulted in the rapid spread of cholera from the Russian empire further to the west is also dubious (2).

The first cases of cholera occurred in England in October 1831 in the port of Sunderland after a ship from Riga had arrived. From Sunderland, cholera spread northward to Scotland and southward to London. In the beginning of 1832, London and Paris were under its sway (1).

There were two theories about the origin of the epidemic at the time. The miasma theory - according to which the causative factor was to be fumes arising in wetlands or areas damaged by adverse weather conditions or even fluids of cosmic origin. The contagionistic theory - suggesting the presence of some living infectious agent which can spread from person to person. The first theory was favoured more (6).
WSTĘP

Druga pandemia cholery miała początek w 1829 roku w Indiach, skąd rozprzestrzeniła się do Rosji, okupowanej przez zaborców Polski, Niemiec, Szwecji, Austrii i Anglii, objęła też Chiny i USA (1). Rozprzestrzenianiu się różnych epidemii sprzyjało masowe przemieszczanie się ludności związane $\mathrm{z}$ chęcią poprawy warunków życia lub z działaniami o charakterze militarnym jak: mobilizacja, wojny, uchodźctwo, demobilizacja. Pojawienie się cholery wywoływało niekiedy niepokoje społeczne (2). Mimo, że powstanie listopadowe zbiegło się w czasie $\mathrm{z}$ epidemią cholery w 1831 r., zauważyć należy, że nie było ono jej skutkiem. Wprawdzie nieliczne szpitale nie zapewniały należytej opieki. Ludność nie chciała do nich oddawać chorych. Nie było jednak buntów związanych z nieufnością do lekarzy, do których dochodziło w innych miastach Europy $(2,3)$. Komitet Centralny Zdrowia 26 lipca 1831 r. powołał lekarzy wolno praktykujących do pomocy lekarzom obwodowym, celem leczenia i udzielania pomocy w domach prywatnych (4) był to pierwszy w świecie odpowiednik dzisiejszego lekarza rodzinnego. Celem powstania nie była też zmiana relacji społecznych, co głosiła strona rosyjska, by zniechęcić innych do jakiejkolwiek pomocy Polakom. Ponieważ walczono o niepodległość Polacy nie mogli uznać proklamacji cara (5). Wątpliwości budzi też pogląd, że związana z powstaniem emigracja polskich uchodźców spowodowała szybkie przemieszczanie cholery z imperium rosyjskiego dalej na zachód (2). Pierwsze zachorowania na cholerę pojawiły się w Anglii w październiku w 1831 r. w porcie Sunderland po przybyciu statku z Rygi. Z Sunderland cholera rozprzestrzeniła się w kierunku północnym do Szkocji i południowym do Londynu. W początku 1832 r. panowała w Londynie i Paryżu (1).

$\mathrm{Na}$ temat pochodzenia epidemii panowały wówczas dwie teorie: Miazmatyczna - według której czynnikiem sprawczym miały być wyziewy powstające w miejscach podmokłych czy zniszczonych pod wpływem niekorzystnych warunków atmosferycznych lub fluidów nawet kosmicznego pochodzenia. Kontagionistyczna - sugerująca obecność żywego czynnika zakaźnego mogącego przenosić się z człowieka na człowieka. Większą przychylnością cieszyła się pierwsza teoria (6). 
The clinical symptoms of cholera were first described by Karol Kaczkowski on April 13, 1831 (7). In 1854, Filippo Pacini discovered and described Vibrio cholerae (1), but it had yet to be shown that it causes people to contract cholera. Robert Koch was the second doctor to isolate the bacterium from the intestines of those who died of cholera in 1883. However, it did not cause cholera symptoms in experimental animals. Cholera had not been recognized as an infectious disease caused by Vibrio cholerae until 1884 when laboratory employees contracted cholera. Today, 12 types of Vibrio cholerae are considered pathogenic to humans. Strains O1 and O139 have the ability to produce cholera toxin (CT) and can cause a pandemic. $V$. cholerae also secretes other toxic substances, e.g. neuroamidase, which supports CT function. The pathomechanism of cholera was not discovered until 1953 (8). Today we know that the effect of the cholera toxin on the small intestinal epithelium causes inhibition of $\mathrm{Na}^{+}$recycling (9), secretion of water into the lumen of the small intestine, diarrhoea. Stools are produced with no pressure and without the possibility of stopping. Dehydration occurs. In a severe course of the disease, shock, coma and then death occur. During one of the nineteenth century epidemics of cholera $53.6 \%$ of patients died in Konin poviat (10).

Little is known about the relationship between deaths and age during the cholera epidemic in 1831. Although the cause of deaths was recorded in the Latin version of death certificates in the Roman Catholic parish in Tuliszków, this information was not used in existing studies. By using the data available in the archives combined with our current computing power, we gain the possibility to better understand the relationship between deaths caused by cholera and the age of the diseased.

\section{OBJECTIVE OF THE PRESENT PAPER}

In the study, the percentage of people who died of cholera in 1831 was compared to the percentage of people who died for other reasons in the year when there was no epidemic, both numbers were examined for the same age groups.

\section{MATERIALS AND METHODS}

In the period of interest to us Tuliszków administratively belonged to the Konin poviat, and the Tuliszków parish to the Włocławek-Kalisz Diocese (Dioecesis Vladislaviensis seu Calissiensis) and the Konin deanery (Decanatus Koninensis). Therefore, with particular attention, the query was made of the files of the town of Tuliszków which are kept in the State Archives in Poznań, Konin Branch (APP o/
Kliniczne objawy cholery pierwszy opisał Karol Kaczkowski 13 kwietnia 1831 roku (7). W 1854 r. Filippo Pacini wykrył i opisał przecinkowca cholery (1) należało jednak wykazać, że powoduje on zachorowanie na cholerę u ludzi. Robert Koch jako drugi wyizolował z jelit zmarłych na cholerę w 1883 r. bakterię. Jednak nie powodowała ona objawów cholery u zwierząt doświadczalnych. Dopiero zachorowanie pracowników laboratorium przyczyniło się do uznania cholery za chorobę zakaźną (1884 r.) wywoływaną przecinkowcem cholery. Obecnie za chorobotwórcze dla człowieka uznaje się 12 gatunków z rodzaju Vibro. Szczepy O1 i O139 maja zdolność produkcji toksyny cholerycznej (CT) i mogą stać się przyczyną pandemii. $V$. cholerae wydziela też inne substancje toksyczne np. neuroamidazę, która wspomaga działanie CT. Dopiero w 1953 r. poznano patomechanizm cholery (8). Obecnie wiemy, że działanie toksyny cholery na nabłonek jelita cienkiego powoduje hamowanie recyklingu $\mathrm{Na}^{+}$ (9) wydzielanie wody do światła jelita cienkiego, biegunkę. Stolce oddawane są bez parcia i bez możliwości zatrzymania. Następuje odwodnienie organizmu. W ciężkim przebiegu choroby dochodzi do wstrząsu śpiączki i zgonu. Podczas jednej z XIX wiecznych epidemii cholery w powiecie konińskim spośród chorych $53,6 \%$ zmarło (10).

Niewiele wiadomo o zależności zgonów od wieku podczas epidemii cholery w 1831 roku. Mimo, że w parafii rzymskokatolickiej w Tuliszkowie w łacińskiej wersji akt zgonów odnotowano przyczynę zgonów, informacji tej nie wykorzystano w istniejących opracowaniach. Korzystając $\mathrm{z}$ danych dostępnych w archiwach i mocy obliczeniowych, jakimi dysponujemy obecnie, uzyskujemy możliwość lepszego poznania zależności zgonów spowodowanych cholerą od wieku.

\section{CEL PRACY}

Zbadano, w takich samych grupach wieku, zmianę odsetka osób zmarłych na cholerę w 1831 roku w porównaniu do odsetka osób zmarłych z innych przyczyn w roku, w którym epidemii nie było.

\section{MATERIAŁ I METODY}

W interesującym nas okresie Tuliszków należał administracyjnie do powiatu konińskiego, a parafia Tuliszków do Diecezji Włocławsko-Kaliskiej (Dioecesis Vladislaviensis seu Calissiensis) i Dekanatu Konińskiego (Decanatus Koninensis). Dlatego ze szczególną uwagą dokonano kwerendy akt miasta Tuliszkowa znajdujących się w Archiwum Państwowym w Poznaniu Oddział w Koninie (APP o/Konin) oraz akt parafii Tuliszków znajdujące się w Archiwum Diecezjalnym 
Konin) and the files of the Tuliszków parish kept in the Diocesan Archives in Włocławek (ADW). Polish Medical Bibliography was also searched, which included information on cholera published in the 19th century (11), as well as Polish Medical Bibliography database in General Medical Library and PubMed database. The bibliography was searched with the terms: cholera, cholera epidemic, deaths, Tuliszków, 1831, Holy Spirit Hospital, Konin.

To analyze deaths in the Roman Catholic parish in Tuliszków during the cholera epidemic in 1831, data from death certificates from 1813-1836 (12) and death certificates from 1826-1834 (13) were used. Data for the control group were chosen for those who died in the year when the cholera epidemic did not occurr. Deaths in the years 1829-1839 were taken into account. It was assumed that due to eating habits, hygiene habits and population numbers, it should not be a year too distant in time from the year of the epidemic (1831). The number and percentage of deaths of the parishioners were identified for each year from 1829 to 1839. For this purpose, data from the files were used $(14,15)$. In addition, data in the catalogues with numbers of parishioners for each calendar year were used respectively from 1829 to 1831 (16), the catalogue for 1832 did not provide the number of parishioners (17). Data from 1833 to 1837 are in the catalogues (18), while for 1838 and 1839 in the records (19). The results obtained are summarized in the table (Tab. I). In 1835, both the percentage of deaths of the parishioners (2.1\%) and the number of deaths (61) were the lowest in the eleven years under consideration. In addition, cholera was not recorded as the cause of death in the files for this year. Also other causes of deaths did not form a series that could indicate an epidemic (12). Therefore, deaths in 1835 were accepted as not caused by cholera (control group). The age of people who died of cholera as well as those who died for other reasons, recorded in death certificates, by days, weeks or months, was converted into a fraction of a year, assuming 365 days a year. First, the data of people who died of cholera were ordered by age at death, from the lowest to the highest value, then they were divided into age groups. The same age groups were adopted for those who died for other reasons in the control year. The numbers of the deceased in the study group ( 81 people) and in the control we Włocławku (ADW). Przeszukano również Polską Bibliografię Lekarską obejmującą publikacje dotyczące cholery, które ukazały się w XIX wieku (11), a także bazę danych Polskiej Bibliografii Lekarskiej GBL oraz bazę PubMed. Bibliografię przeszukiwano stosując hasła: cholera, epidemia cholery, zgony, Tuliszków, rok 1831, szpital św. Ducha, Konin.

Do przeprowadzenia analizy zgonów w parafii rzymskokatolickiej w Tuliszkowie podczas epidemii cholery w $1831 \mathrm{r}$. wykorzystano dane zawarte w aktach zgonów z lat 1813-1836 (12) i aktach zgonów z lat 1826-1834 (13). Jako dane do grupy kontrolnej wybrano dane osób zmarłych w roku, w którym epidemii cholery nie było. Pod uwagę wzięto zgony w latach od 1829 do 1839 roku. Uznano bowiem, iż ze względu na zwyczaje żywieniowe, nawyki higieniczne i liczbę mieszkańców, nie powinien to być rok zbyt odległy od roku epidemii (1831). Ustalono liczbę i procent zgonów wiernych w poszczególnych latach od 1829 do 1839 roku. W tym celu wykorzystano dane z akt $(14,15)$. Dodatkowo wykorzystano dane zawarte w katalogach, które podawały liczbę parafian na każdy rok kalendarzowy. Odpowiednio dla lat 1829 do 1831 w katalogach (16), w katalogu na rok 1832 nie podano liczby parafian (17). Dane od roku 1833 do 1837 znajdują się w katalogach (18), natomiast dla lat 1838 i 1839 w elenchus (19). Otrzymane wyniki zestawiono w tabeli (Tab. I). W roku 1835 zarówno procent zgonów wiernych (2,1\%), jak i liczba zgonów (61) były najmniejsze w rozpatrywanych jedenastu latach. Poza tym wśród przyczyn zgonu w aktach $\mathrm{z}$ tego roku nie zapisano cholery. Również inne przyczyny zgonów nie układały się w serie mogące wskazywać na epidemię (12). Dlatego zgony w roku 1835 przyjęto jako niespowodowane cholerą (grupa kontrolna). Wiek osób zmarłych na cholerę, jak i zmarłych $z$ innych przyczyn zapisany w aktach zgonów w dniach, tygodniach lub miesiącach, przeliczono na ułamek roku, przyjmując liczbę 365 dni w roku. Po uporządkowaniu danych osób zmarłych na cholerę, według wieku w chwili zgonu, od wartości najmniejszej do największej, dokonano podziału na grupy wieku. Takie same grupy wieku przyjęto dla zmarłych z innych przyczyn w roku kontrolnym. Liczby zmarłych w grupie badanej (81 osób) jak i w grupie kontrolnej (61 osób) nie

Table I. Numbers and percentages of deaths in the Roman Catholic parish in Tuliszków in the years 1829-1839.

Tabela I. Liczby i procenty zgonów w parafii rzymskokatolickiej Tuliszków w latach 1829 - 1839.

\begin{tabular}{|c|c|c|c|c|c|c|c|c|c|c|c|}
\hline & \multicolumn{11}{|c|}{ Years } \\
\hline & 1829 & 1830 & 1831 & 1832 & 1833 & 1834 & 1835 & 1836 & 1837 & 1838 & 1839 \\
\hline Number of deaths & 163 & 107 & 169 & 100 & 136 & 78 & 61 & 64 & 96 & 69 & 83 \\
\hline $\begin{array}{l}\text { Number of } \\
\text { parishioners }\end{array}$ & 2621 & 2606 & 2870 & - & 2891 & 2895 & 2904 & 2803 & 2935 & 2930 & 2880 \\
\hline$\%$ of deaths & 6.21 & 4.1 & 5.88 & - & 4.7 & 2.69 & 2.1 & 2.28 & 3.27 & 2.35 & 2.88 \\
\hline
\end{tabular}


group (61 people), due to the mathematical requirements of the test, do not allow for a more detailed division of the age groups, and thus for a separate analysis for men and women in individual age groups.

\section{STATISTICAL ANALYSIS}

In the study group as well as in the control group, all data of the deceased were readable. 61 people in the control group and 81 people in the study group were analyzed. Data were analyzed by Fisher's test using Statistica software. The differences were considered statistically significant for $p$-values $\leq 0.05$.

\section{RESULTS}

Given the dates of deaths, the first death from cholera in 1831 was recorded in Tuliszków on August 8 (death certificate 61), and the last one on October 5 (death certificate 146). It should be added, however, that a single death due to this reason occurred in Tuliszków also on December 13 (death certificate 166). After this event, nobody died of cholera until the end of 1832 . An increased number of deaths in villages in March and April 1831 (Fig. 1) was not caused by cholera, as other causes of death were recorded in the files. Outside Tuliszków, deaths from cholera occurred only in Sarbicko, where the first person died on August 26 (death certificate 83) and the last person on October 10 (death certificate 148) (12). Therefore, deaths took place in the parish from August 8 to October 10. At that time, the parish had 2,870 parishioners (16). Throughout 1831, 169 people died, accounting for $5.88 \%$ of parishioners. Of these, 81 people died of cholera, accounting for $47.93 \%$ of all deaths. Due to cholera 74 people died in pozwalają, ze względu na matematyczne wymogi testu, na zbyt szczegółowy podział na grupy wieku, a co za tym idzie oddzielną analizę dla kobiet i mężczyzn w poszczególnych grupach wieku.

\section{ANALIZA STATYSTYCZNA}

W grupie badanej, jak i w grupie kontrolnej wszystkie dane osób zmarłych były czytelne. Analizie poddano 61 osób w grupie kontrolnej i 81 osób w grupie badanej. Dane analizowano testem Fishera z wykorzystaniem programu Statistica. Różnice uznano za istotne statystycznie dla wartości $\mathrm{p} \leq 0,05$.

\section{WYNIKI}

Biorąc pod uwagę daty zgonów, pierwszy zgon spowodowany cholerą w 1831 roku w Tuliszkowie odnotowano 8 sierpnia (akt zgonu nr 61), a ostatni 5 października (akt zgonu 146). Należy jednak dodać, że pojedynczy zgon z tej przyczyny zdarzył się w Tuliszkowie jeszcze 13 grudnia (akt zgonu 166). Po tym zdarzeniu, na cholerą nie zmarł nikt do końca 1832 roku. Zwiększona liczba zgonów na wsiach w marcu i kwietniu 1831 r. (Ryc. 1) nie była spowodowana cholerą, bowiem w aktach zapisano inne przyczyny zgonów. Poza Tuliszkowem zgony z powodu cholery miały miejsce tylko w Sarbicku, gdzie pierwsza osoba zmarła 26 sierpnia (akt zgonu 83), a ostatnia 10 października (akt zgonu 148) (12). W parafii zgony trwały więc od 8 sierpnia do 10 października. Parafia liczyła wówczas 2870 wiernych (16). W ciągu całego roku 1831 zmarło 169 osób, stanowiło to 5,88 \% parafian. Wśród nich osiemdziesiąt jeden osób zmarło na cholerę, co stanowiło $47,93 \%$ wszystkich zgonów. Z powo-

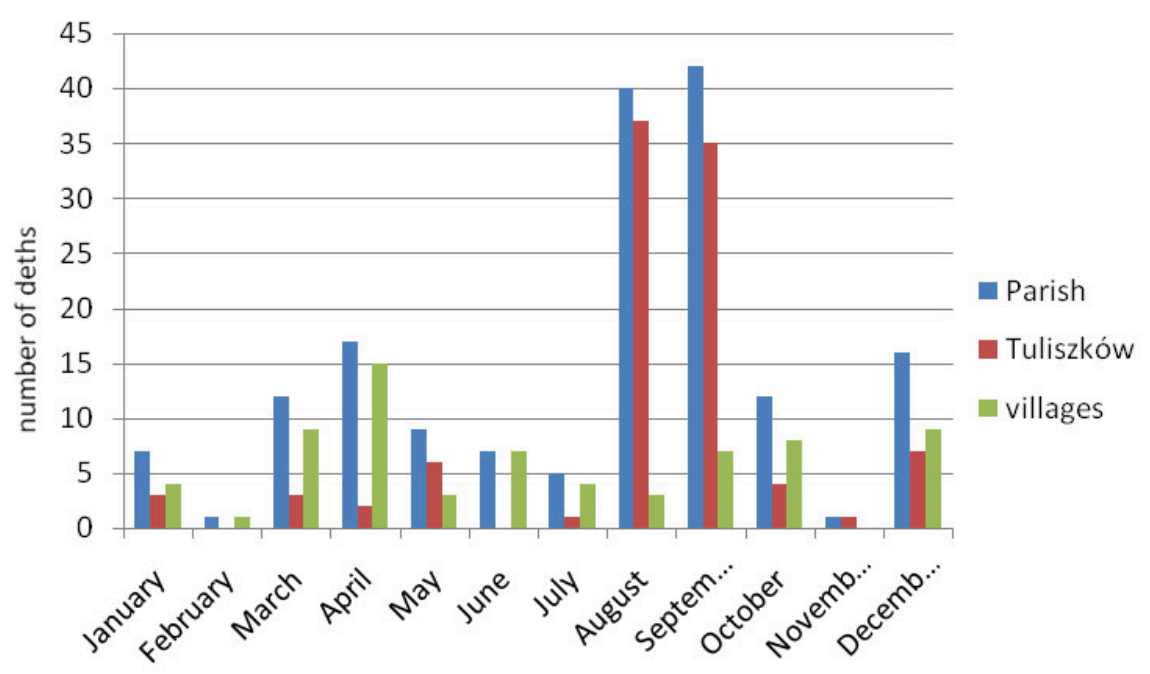

Fig. 1. The number of deaths in individual months during 1831 in Tuliszków parish, in Tuliszków and in the villages around. Based on death certificates of the Roman Catholic parish in Tuliszków (12)

Ryc. 1. Liczby zgonów w poszczególnych miesiącach 1831 roku w parafii Tuliszków, w Tuliszkowie i na wsiach. Na podstawie akt zgonów parafii rzymskokatolickiej Tuliszków (12) 
Tuliszków, and 7 people in Sarbicko. In the comparative year (1835) 61 people died in the parish: 20 people in Tuliszków, and 8 in Sarbicko. In the remaining villages of the parish 33 people died (15).

The graph (Fig. 2) and table (Tab. II) show that when there was no epidemic (1835) the percentage of deaths in infants and children under the age of 5 was high (52.46\%). However, during the epidemic (1831) it was lower, but it amounted to $28.40 \%$. In this age group there was a statistically significant difference between the number of deaths caused by cholera and the number of deaths due to other causes (in the control year) (Tab. III). A significant increase in the percentage of deaths occurred in the group of people aged 21 to 40 : from $13.11 \%$ to $23.46 \%$. It was higher than in the group of people over the age of 55, in which it increased from $9.84 \%$ to $19.75 \%$ (Tab. II). du cholery w Tuliszkowie zmarły 74 osoby, a w Sarbicku 7 osób. W roku porównawczym (1835) w parafii zmarło 61 osób: w Tuliszkowie 20 osób, a w Sarbicku 8 . W pozostałych wsiach parafii zmarły 33 osoby (15).

Z wykresu (Ryc. 2) i (Tab. II) wynika, że kiedy nie było epidemii (1835) odsetek zgonów wśród niemowląt i dzieci do lat pięciu był wysoki $(52,46 \%)$. Natomiast podczas epidemii (1831) był mniejszy, jednak wynosił aż $28,40 \%$. W tej grupie wieku wystąpiła różnica istotna statystycznie pomiędzy liczbą zgonów spowodowanych cholerą a liczbą zgonów z innych przyczyn (w roku kontrolnym) (Tab. III). Znaczny wzrost odsetka zgonów nastąpił w grupie osób w wieku od 21 do 40 lat z $13,11 \%$ do $23,46 \%$. Był on wyższy niż w grupie osób powyżej 55 roku życia, w której wzrósł z 9,84\% do $19,75 \%$ (Tab. II).

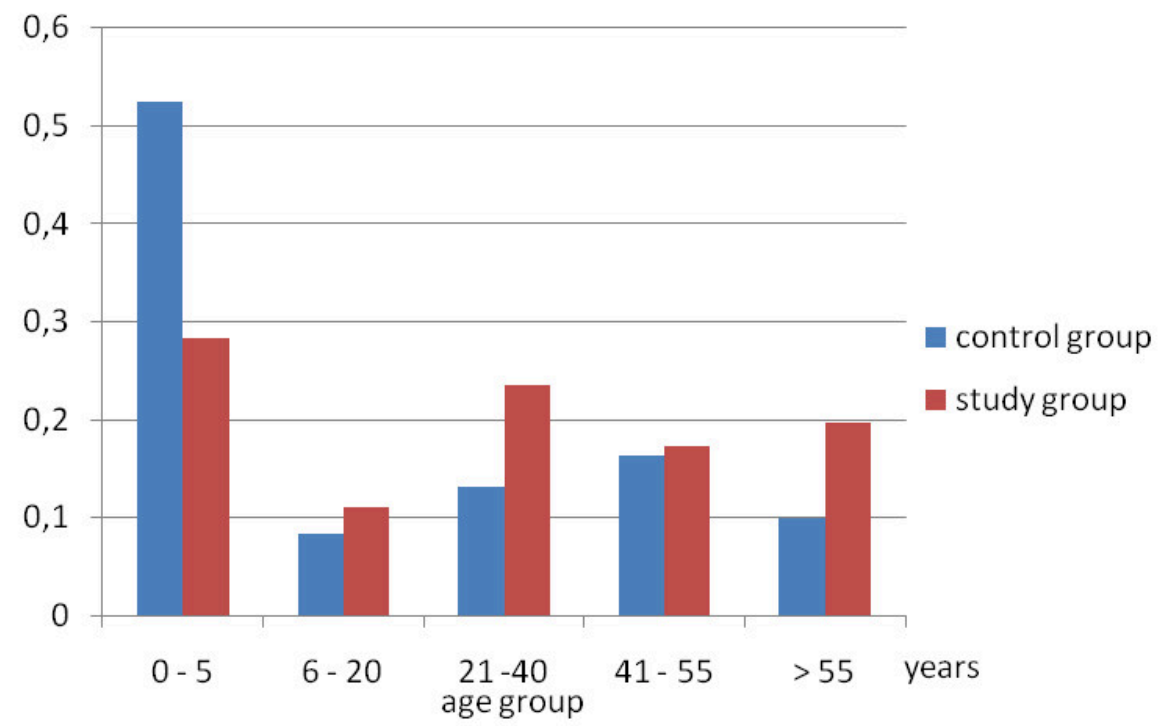

Fig. 2. Percentage distribution of deaths in individual age groups in Tuliszków in 1835 (control group) and those who died of cholera in 1831 (study group)

Ryc. 2. Rozkład procentowy zgonów w poszczególnych grupach wieku w Tuliszkowie w roku 1835 (grupa kontrolna) i zmarłych na cholerę w roku 1831 (grupa badana)

Table II. The percentage distribution of deaths and their numbers in individual age groups in the control group (those who died for other reasons) and in the study group (those who died of cholera)

Tabela II. Rozkład procentowy zgonów i ich liczba w poszczególnych grupach wieku w grupie kontrolnej (zmarłych z innych przyczyn) i w grupie badanej (zmarłych na cholerę)

\begin{tabular}{|c|c|c|c|}
\hline & Control group & Study group & Total in a row \\
\hline $0-5$ & 32 & 23 & 55 \\
\hline $6-20$ & $52.46 \%$ & $28.40 \%$ & 14 \\
\hline $21-40$ & 5 & 9 & 27 \\
\hline $41-55$ & $8.20 \%$ & $11.11 \%$ & 24 \\
\hline & 8 & $23.46 \%$ & 19 \\
\hline 56 & $13.11 \%$ & $17.28 \%$ & 22 \\
\hline
\end{tabular}


Table III. Distribution of the number of deaths in the individual age groups in the control group (1835) and in the study group (1831). Analyzed by the Fisher test

Tabela III. Rozkład liczb zgonów w poszczególnych grupach wieku w grupie kontrolnej (rok 1835) i w grupie badanej (rok 1831 r.). Analizowano testem Fishera

\begin{tabular}{|c|c|c|c|}
\hline & Control group & Study group & p-value \\
\hline $0-5$ & 32 & 23 & 0,0052 \\
\hline $6-20$ & 5 & 9 & 0,7773 \\
\hline $21-40$ & 8 & 19 & 0,1356 \\
\hline $41-55$ & 10 & 14 & 1,0000 \\
\hline 56 & 6 & 16 & 0,1589 \\
\hline
\end{tabular}

\section{DISCUSSION}

In years 1830-1831, no medical magazine was published in Polish lands under the Russian rule (4). For this reason, studies on the epidemic of 1831 come from later years. However, no description of the epidemic in Tuliszków was found among them. Based on the death dates of people who died of cholera, it could be assumed that the epidemic in the Tuliszków parish in 1831 lasted from August 8 to October 10. However, given the incubation period of the disease, which lasts from several hours to five days, and the fact that not all patients were dying, the above dates should not be equated with the beginning and the end of the epidemic. They are only approximate dates. Excluding year 1831, when the epidemic prevailed, the average number of deaths (87) from 1829 to 1839 was significantly lower than the number of deaths in 1829 and 1833 (Fig. 3). In 1829, the percentage of deaths $(6.21 \%)$ was even higher than in the year of the cholera epidemic (5.88\%) (Tab. I). On the one hand, it may indicate that there was another epidemic in 1829 , and on the other, that the cholera epidemic in 1831 in

\section{DYSKUSJA}

W latach 1830-1831 na ziemiach polskich zabranych przez Rosję nie wychodziło żadne czasopismo lekarskie (4). Z tego powodu opracowania dotyczące epidemii w $1831 \mathrm{r}$. pochodzą z lat późniejszych. Jednak nie znaleziono wśród nich opisu epidemii w Tuliszkowie. Na podstawie dat zgonów osób zmarłych na cholerę można by przyjąć, że w 1831 roku epidemia w parafii Tuliszków trwała od 8 sierpnia do 10 października. Jednak biorąc pod uwagę okres wylęgania choroby trwający od kilku godzin do pięciu dni oraz to, że nie wszyscy chorzy umierali, nie należy utożsamiać powyższych dat z początkiem i końcem epidemii. Są one jedynie datami przybliżonymi. Średnia liczba zgonów (87) z lat 1829 do 1839 z wyłączeniem roku 1831, w którym panowała epidemia, była znacznie niższa od liczby zgonów w latach: 1829 i 1833 (Ryc. 3). W roku 1829 odsetek zgonów (6,21 \%) był nawet większy niż w roku epidemii cholery (5,88 \%) (Tab. I). Z jednej strony może świadczyć to, że w roku 1829 występowała inna epidemia, z drugiej zaś, że epidemia cholery w $1831 \mathrm{r}$. w Tuliszkowie nie miała zbyt gwałtownego

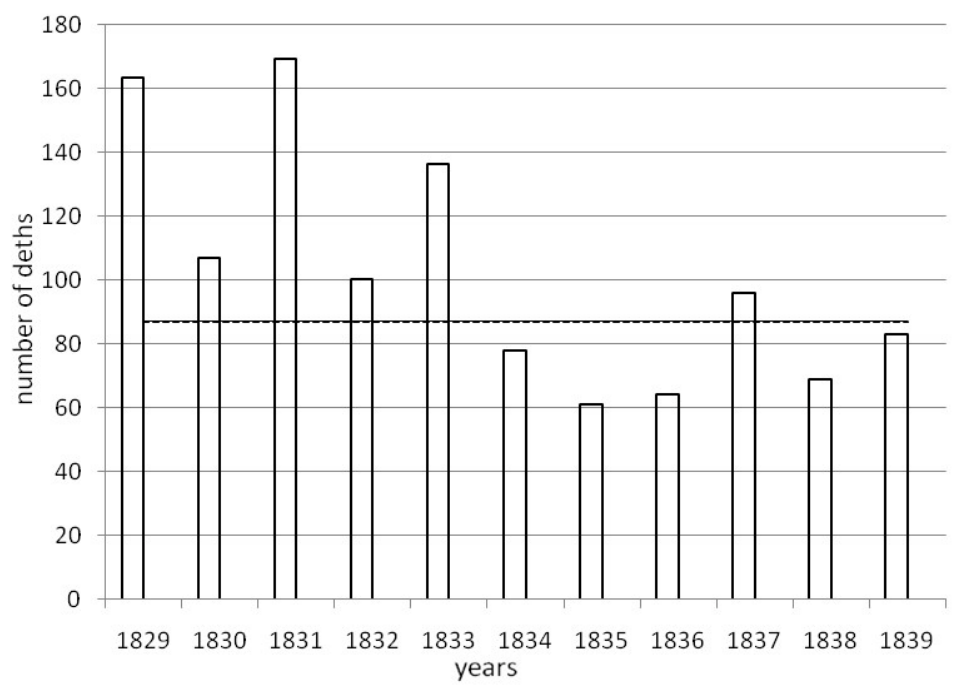

Fig. 3. Numbers of deaths for residents of Tuliszków parish in individual years. The marked average excludes the year 1831 (cholera epidemic)

Ryc. 3. Liczby zgonów mieszkańców parafii Tuliszków w poszczególnych latach. Zaznaczona średnia bez roku 1831 (epidemia cholery) 
Tuliszków was not too rapid in its course. When the numbers of deaths in 1829 were added up, they were categorized according to the causes of death recorded in the files. 45 deaths from an unknown disease (morbo ignato) and 39 deaths caused by smallpox were distinguished (12). The latter was also called pimple in Polish at that time due to pustules with leaking fluid, which was a symptom of a certain stage of the disease (20). There were also 7 people who died of tuberculosis. However, there were no deaths from cholera. Thus we conclude that the cholera epidemic in 1831 in the Tuliszków parish was not too violent. This conclusion is confirmed by the fact that cholera did not spread to nearby villages except for Sarbicko. The epidemic in 1831 was assessed as "relatively mild" also in the paper (21).

The number of deaths in infants and children under the age of 5 was in fact significantly lower than in other age groups $(\mathrm{p}=0.0052)$. A publication from 1831 noted that cholera in children "subsides very easily" (22). On the other hand, according to the authors of the paper (21), infants almost never contracted cholera. Today we know that breastfeeding does not protect against $V$. cholerae infection, but against the development of the disease (23). Sialyllactose in mother's milk plays an important role in neutralizing cholera toxin (24). This may be one of the reasons for the lower death rate in the age group up to 5 years, because infants and sometimes older children were breastfed. However, the highest percentage of deaths from cholera occurred in the age group from 21 to 40 (Fig. 2). This could have been influenced by several factors (25), including, among others, high professional and sexual activity in this age group combined with lack of hygiene. The results obtained in this study confirm the accuracy of some of the observations presented in the publications (21, 22 ) and are consistent with the results of contemporary publications $(23,24,25)$.

Identifying the increase in the percentage of deaths in the group from 21 to 40 allows for a better appreciation of the achievements of Polish doctors: Karol Kaczkowski and Karol Marcinkowski. In 1831, along with the cholera epidemic, the November Uprising continued. Meanwhile, a significant proportion of men capable of carrying weapons were recruited from this age group. The Surgeon General of the Polish army, Karol Kaczkowski, was aware that the insurgent fighting units were in great danger of contracting cholera. The sick soldiers were sent to hospitals where they were isolated from the wounded. Separate hospitals for cholera patients were established. Drinking from contingent water reservoirs was banned. This was all before the discoveries by John Snow, Filippo Pacini and Robert Koch. The fight against cholera in the Polish Army in 1831 became przebiegu. Po podsumowaniu liczby zgonów w roku 1829, według przyczyn śmierci zapisanych w aktach wyodrębniono 45 zgonów na nieznaną chorobę (morbo ignato) i 39 zgonów spowodowanych ospą (12), którą wówczas ze względu na ulegające zropieniu pęcherzyki, będące objawem pewnego stadium choroby, nazywano także krostą (20). Z kolei siedem osób zmarło na gruźlicę. Nie odnotowano natomiast zgonów na cholerę. Wnioskujemy z tego, że epidemia cholery w 1831 roku w parafii Tuliszków nie należała do zbyt gwałtownych. Wniosek taki potwierdza fakt, że cholera nie rozszerzyła się na bliskie wsie z wyjątkiem Sarbicka. Epidemię w 1831 r. oceniono jako „względnie łagodną" również w pracy (21).

Liczba zgonów niemowląt i dzieci do lat 5 spowodowana cholerą była istotnie mniejsza niż w pozostałych grupach wieku $(\mathrm{p}=0.0052)$. Już w publikacji z 1831 roku zauważono, że cholera u dzieci „bardzo łatwo ustępuje" (22). Z kolei według autorów pracy (21) niemowlęta prawie nigdy nie zapadały na cholerę. Obecnie wiemy, że karmienie piersią nie chroni przed zarażeniem $V$. cholerae, lecz przed rozwojem choroby (23). Istotną rolę w neutralizowaniu toksyny cholery odgrywa zawarta w mleku matki sialyllaktoza (ang. sialyllactose) (24). Może to być jedną z przyczyn mniejszego odsetka zgonów w grupie wieku do lat 5, bowiem niemowlęta, a niekiedy dzieci starsze były karmione piersią. Natomiast największy odsetek zgonów spowodowanych cholerą wystąpił w grupie wieku od 21 do 40 lat (Ryc. 2). Wpływ na to mogło mieć kilka czynników (25), w tym między innymi duża w tej grupie wieku aktywność zawodowa i seksualna połączona $\mathrm{z}$ brakiem higieny. Wyniki otrzymane w tej pracy potwierdzają trafność niektórych spostrzeżeń zawartych w publikacjach $(21,22)$ i są zgodne z wynikami publikacji współczesnych $(23,24,25)$.

Ustalenie wzrostu odsetka zgonów w grupie od 21 do 40 lat pozwala bardziej docenić osiągnięcia polskich lekarzy: Karola Kaczkowskiego i Karola Marcinkowskiego. W 1831 roku wraz z epidemią cholery trwały walki powstania listopadowego. Tymczasem znaczna część mężczyzn zdolnych do noszenia broni rekrutowała się z tej grupy wieku. Naczelny lekarz wojska polskiego, Karol Kaczkowski zdawał sobie sprawę z wielkiego niebezpieczeństwa zachorowań na cholerę dla walczących oddziałów powstańczych. Chorych żołnierzy odsyłano do szpitali, gdzie byli izolowani od rannych. Zakładano oddzielne szpitale dla chorych na cholerę. Wydano zakaz picia wody z przygodnych zbiorników. Działo się to przed odkryciami Johna Snowa, Filippo Paciniego i Roberta Kocha. Walka z cholerą w Wojsku Polskim w 1831 r. stała się wzorem postępowania profilaktycznego dla świata lekarskiego krajów Europy Zachodniej, a także przeciwnika walk - Rosji (26). Z Karolem Kaczkowskim współpracował 
a model of preventive treatment for the medical world of Western European countries as well as for the opponent of the insurgence - Russia (26). Karol Marcinkowski cooperated with Karol Kaczkowski. Science societies of England, France and Prussia sent doctors to Warsaw in order to learn about ways to fight the epidemic and treat cholera (4). During the cholera epidemic in Paris in August 1832, Marcinkowski sent information about cholera to French doctors, for which he received a gold medal worth 1000 francs from the French Academy of Sciences, which he offered to the emigration Society for Scientific Assistance to support students of medicine (27).

Deaths from cholera, especially among people between the ages of 21 and 40, had serious social consequences. They deprived some families of their only breadwinners or of two working hands and contributed to the rise of poverty. There was also the risk of both parents dying and children being orphaned. The theme of orphans left behind after epidemics was reflected in Polish art of the nineteenth century, among others in paintings by M.E. Andriolli "Mum's gone, Johnnie" (1874), or by A. Bilińska-Bohdanowicz "Children waking dead mother" (approx. 1880). These issues require a separate study from the point of view of history and economy.

\section{CONCLUSIONS}

1. The number of deaths in infants and children under the age of 5 caused by cholera in the Tuliszków parish in 1831 was significantly lower than in other age groups $(\mathrm{p}=0.0052)$.

2. The increase in the percentage of deaths caused by cholera compared to deaths from other causes (in 1835) was the largest in the age group from 21 to 40 years. However, among infants and children under 5 years of age it decreased.

3. An outbreak of cholera in the Tuliszków parish in 1831 began around August 8 and lasted until around October 10. 81 people died of cholera. These deaths took place only in Tuliszków (74 people) and in Sarbicko (7 people).

\section{REFERENCES}

1. Awofeso N, Aldabk K. Cholera, migration, and Global Health - a critical review. Int J Travel Med Glob Health 2018;6(3):92-99.

2. Evans R J. Epidemics and revolutions: cholera in nineteenth-century Europe. Post Present 1988;120:123-146.

3. Burrell S, Gil G. The Liverpool cholera epidemic of 1832 and anatomical dissection - medical mistrust and civil unrest. J Hist Med Allied Sci, 2005;60(4):478-98.
Karol Marcinkowski. Towarzystwa naukowe Anglii, Francji i Prus wysyłały do Warszawy lekarzy w celu zapoznania się ze sposobami zwalczania epidemii i leczenia cholery (4). W czasie epidemii cholery w Paryżu w sierpniu 1832 Marcinkowski udzielił informacji o cholerze lekarzom francuskim, za co otrzymał od Francuskiej Akademii Nauk złoty medal wartości 1000 franków, który ofiarował emigracyjnemu Towarzystwu Pomocy Naukowej na wsparcie dla studentów medycyny (27).

Zgony spowodowane cholerą szczególnie wśród osób w wieku od 21 do 40 lat pociągały za sobą poważne skutki społeczne. Pozbawiały część rodzin jedynych żywicieli, a dwór rąk do pracy i przyczyniały się do wzrostu biedy. Wiązały się również z ryzykiem śmierci obojga rodziców i osierocenia dzieci. Pozostawanie wielu sierot po epidemiach znalazło odzwierciedlenie w malarstwie polskim XIX wieku, między innymi u M. E. Andriollego „Nie ma Jaśku mamy” (1874), A. Bilińskiej-Bohdanowicz „Dzieci budzące zmarłą matkę" (ok. 1880). Zagadnienia te wymagają odrębnego opracowania pod względem historycznoekonomicznym.

\section{WNIOSKI}

1. Spowodowana cholerą w 1831 roku w parafii Tuliszków liczba zgonów niemowląt i dzieci do lat 5 była istotnie mniejsza niż w pozostałych grupach wieku $(\mathrm{p}=0.0052)$.

2. Wzrost odsetka zgonów spowodowanych cholerą w porównaniu do zgonów $\mathrm{z}$ innych przyczyn (w 1835 r.) był największy w grupie wieku od 21 do 40 lat. Natomiast wśród niemowląt i dzieci do lat 5 zmalał.

3. Epidemia cholery w parafii Tuliszków w 1831 roku miała początek około 8 sierpnia i trwała do około 10 października. Na cholerę zmarło 81 osób. Zgony te miały miejsce tylko w Tuliszkowie (74 osoby) i w Sarbicku (7 osób).

4. Goździk P. W. Cholera w Królestwie Polskim w 1831 roku. Lekarz Wojskowy 1938; 31(1): 67-89, 31(3): 316-337, 31(2): 224-234.

5. Staszewski J. Gen. Michał Mycielski. Udział rodziny Mycielskich w powstaniu listopadowym. Poznań: Nakład Związku Rodziny Mycielskich; 1930: 20.

6. Szarszewski A. Epidemie cholery w Gdańsku w XIX wieku w Kizik E. Dżuma, ospa, cholera. Gdańsk: Muzeum Historyczne Miasta Gdańska 2012: 198.

7. Chiżyński Z. Obraz kliniczny cholery azjatyckiej w opisach pierwszej epidemii w Polsce w 1831 roku. Pol Tyg Lek 1996;26(30):1177-1178. 
8. Stypułkowska-Misiurewicz H. Tajemnica chorobotwórczości Vibro cholerae przecinkowca cholery w sto lat po śmierci Roberta Kocha. Post Mikrobiol 2010;49(4):317-323.

9. Nakayama M, Ishizuka N, Hempstock W, et al. $\mathrm{Na}+$-coupled nutrient cotransport induced luminal negative potential and claudin-15 play an import role in paracellular $\mathrm{Na}+$ recycling in mouse small intestine. Int J Med Sci 2020;21:376; doi:10.3390/ ijms21020376.

10. Cichy B. Epidemia cholery w Tuliszkowie w 1852 roku. Kronika Wielkopolski 2016;1(157):21-30.

11. Konopka S. Polska bibliografia lekarska dziewiętnastego wieku (1801-1900). Tom II. Warszawa: Wydaw. Lek. PZWL; 1975:106-138.

12. Archiwum Diecezjalne we Włocławku (ADW). Parafia Tuliszków. Księgi metrykalne parafii Tuliszków zgony 1813-1836, sygn. 5112763/2.

13. ADW. Parafia Tuliszków. Księgi metrykalne parafii Tuliszków zgony 1826-1834, sygn. 5112763/7.

14. ADW. Parafia Tuliszków. Księgi metrykalne parafii Tuliszków, zgony 1839 - 1846, sygn. 5112763/3.

15. ADW. Parafia Tuliszków. Księgi metrykalne parafii Tuliszków zgony 1835 - 1852, sygn. 5112763/8.

16. ADW. Koźmian J. Sz. Catalogus Cleri Saecularis ac Regularis Dioecesis Vladislaviensis seu Calissiensis. Anno Domini (odpowiednio dla lat 1829 do 1831). Warszawa: Wyd. Diecezji Włocławsko-Kaliskiej.

17. ADW. Jasiński W. Catalogus Cleri Saecularis ad Cath. Vlad. Anno Domini 1832. Warszawa: Wyd. Administrator Diecezji Włocławsko-Kaliskiej.

18. ADW. Tomaszewski W. M. Catalogus Cleri Saecularis ac Regularis Dioecesis Vladislaviensis seu Calissiensis. Anno Domini (odpowiednio dla lat 1833 do 1837). Warszawa: Wyd. Diecezji Włocławsko-Kaliskiej.

19. ADW. Tomaszewski W. M. Elenchus Cleri Saecularis ac Regularis Dioecesis Vladislaviensis seu Calissiensis Anno Domini (odpowiednio dla lat 1838 i 1839). Warszawa: Wyd. Administrator Diecezji. Włocławsko-Kaliskiej.

20. Encyklopedia Powszechna. Tom 16. Warszawa: Nakład Orgelbranda; 1864:145.

21. Dzierżawski B, Hewelke O, Janowski W, i in. Cholera, jej dawniejsze epidemie u nas, przyczyny, objawy, zapobieganie i leczenie. Warszawa: Wydawnictwo Kroniki Lekarskiej; 1892: 4, 46, 10-11.

22. Malcz W. O cholerze indyjskiej epidemicznej. Warszawa: Nakład autora; 1831:153.

23. Qureshi K, Molbak K, Sandström A, et.al. Breast milk reduces the risk of illness in children of mothers with cholera. Observation from an epidemic of cholera in Guinea-Bissau. Pediatr Infect Dis J 2006;25(12):1163-1166.

24. Idota $T$, Kawakami H, Murakami $Y$, et al. Inhibition of cholera toxin by human milk fractions and sialyllactose. Biosci Biotech Biochem1995;59:417-419.

25. Cichy B. Analiza zgonów w parafii Tuliszków spowodowanych epidemią cholery w 1852 roku. Przegl Epidemiol 2015;69(3):549-554 i 653-656.

26. Krzyś J. Postępowanie profilaktyczne przeciwko cholerze w Wojsku Polskim podczas powstania listopadowego. Arch Hist Med. 1984;47(4):539-550.

27. Gerstenberger J, Stach R. O epidemii cholery azjatyckiej w Poznaniu w 1837 roku. Poznań: Wyd. Adama Wrzoska 1936: 23.

Received: 3.03.2020

Accepted for publication: 1.06.2020

Otrzymano: 3.03.2020 r.

Zaakceptowano do publikacji: $1.06 .2020 \mathrm{r}$.

Address for correspondence:

Adres do korespondencji:

bcichy1@wp.pl 